\title{
PENGARUH PERAN DAN KOMPETENSI PENYULUH PENDAMPING TERHADAP KEBERHASILAN GERAKAN PERCEPATAN PENGANEKARAGAMAN KONSUMSI PANGAN (P2KP) TAHUN 2014 DALAM MENDUKUNG KETAHANAN PANGAN DI KABUPATEN KLATEN
}

The Effect and the Role of Extention Assistant Competency on the Success of the Acceleration Movement of Food Consumption Diversity (P2KP) to Support Food Resilience Klaten Regency

\section{Fajar Sriningsih}

\author{
Sekretariat Daerah Pemerintah Provinsi Kalimantan Tengah \\ E-mail: sriningsih.fjr@gmail.com
}

\begin{abstract}
P2KP movement is one of the pillars of maintaining and improving food security and develops its diverse consumption patterns, Nutritious, Balanced and Safe (B2SA), both quantity and quality in order to improve the quality of people's food consumption. This study aims to determine the effect of the role and competence companion extension to a program associated contribution to food security in the district of Klaten. This study, using a mixture of writing (mixedmethods) is a method of writing quantitative and qualitative methods of writing. The results showed that the role and competence companion extension Movement Acceleration effect on the success of the Food Consumption P2KP to support food security in Klaten Area.
\end{abstract}

Keywords: Role, competence, companion extension, P2KP, food security

\begin{abstract}
Abstrak
Gerakan P2KP merupakan salah satu pilar mempertahankan dan meningkatkan ketahanan pangan serta membudayakan pola konsumsi yang Beragam, Bergizi, Seimbang dan Aman (B2SA), baik jumlah maupun mutunya guna meningkatkan kualitas konsumsi pangan masyarakat. Penelitian ini bertujuan untuk mengetahui pengaruh peran dan kompetensi penyuluh pendamping pada suatu gerakan dikaitkan kontribusinya terhadap ketahanan pangan di Kabupaten Klaten.Penelitian ini menggunakan metode penelitian campuran (mixedmethods) yaitu metode penulisan kuantitatif dan metode penulisan kualitatif. Hasil penelitian menunjukkan bahwa peran dan kompetensi penyuluh pendamping berpengaruh terhadap Gerakan Percepatan Penganekaragaman Konsumsi Pangan terhadap keberhasilan P2KP untuk mendukung Ketahanan Pangan daerah di Kabupaten Klaten.
\end{abstract}

Kata kunci: Peran, Kompetensi, Ketahanan Pangan.

\section{PENDAHULUAN}

Indonesia merupakan salah satu negara dengan mayoritas penduduknya mengkonsumsi beras, yaitu sebesar $94 \%$ dari total jumlah penduduk (BKP, 2011). Data BPS (2012) tahun 2010 menunjukkan jumlah penduduk Indonesia telah mencapai 237,6 juta jiwa dengan laju pertumbuhan sekitar $1,49 \%$ per tahun. Sementara itu, pertumbuhan produktivitas padi di Indonesia hanya berkisar 0,98\% per tahun (Arifin, 2011). Tingkat konsumsi beras masyarakat Indonesia tergolong tinggi, yaitu sebesar 139, $15 \mathrm{~kg} / \mathrm{kapita} / \mathrm{tahun}$ jika dibandingkan dengan rata-rata konsumsi beras dunia sebesar 60 kg/kapita/tahun (BKP, 2013), bahkan tingkat konsumsi beras ini masih 
lebih tinggi dibandingkan dengan penduduk Asia lainnya seperti Malaysia sebesar $80 \mathrm{~kg} / \mathrm{kapita} / \mathrm{tahun}$, Thailand 70 kg/kapita/tahun, Jepang sebesar 50 $\mathrm{kg} / \mathrm{kapita} / \mathrm{tahun}$ dan Korea Selatan sebesar 40 kg/kapita/tahun (BKP, 2012).

Realitas di atas menunjukkan bahwa permasalahan pangan di Indonesia cukup kompleks diantaranya disebabkan oleh jumlah kebutuhan beras yang semakin besar seiring dengan pertumbuhan penduduk dan asupan konsumsi pangan masyarakat yang kurang beragam dan berimbang. Untuk mencukupi kebutuhan beras tersebut sampai saat ini pemerintah masih melakukan impor beras, sedangkan untuk mengatasi masalah pola konsumsi pangan masyarakat yang belum beragam dan berimbang pemerintah menerapkan kebijakan diversifikasi pangan (BPS, 2013).

Sejak tahun 1960, pemerintah telah menerapkan diversifikasi pangan melalui anjuran untuk mengkonsumsi pangan pokok selain beras. Sebagai wujud pentingnya diversifikasi pangan maka pemerintah menunjukkan keseriusan dan komitmennya dengan menggalakkan kembali diversifikasi pangan yang tertuang dalam Rencana Strategis Kementerian Pertanian RI Tahun 20102014 yang difokuskan pada Empat Sukses Pembangunan Pertanian, yaitu (1) pencapaian swasembada dan swasembada yang berkelanjutan; (2) peningkatan diversifikasi pangan; (3) peningkatan nilai tambah dan daya saing ekspor; dan (4) peningkatan kesejahteraan petani.

Pemerintah menunjukkan keseriusan dalam melakukan upaya diversifikasi pangan dengan mengeluarkan Peraturan Presiden Nomor 22 Tahun 2009 tanggal 6 Juni 2009 tentang Kebijakan Percepatan Panganekaragaman Konsumsi Pangan Berbasis Sumber Daya Lokal. Selanjutnya, peraturan ini ditindaklanjuti dengan Peraturan Menteri Pertanian Nomor 43/Permentan/OT.140/10/2009 tentang Gerakan Percepatan Penganekaragaman Konsumsi Pangan Berbasis Sumber Daya Lokal yang selanjutnya dikenal dengan sebutan Gerakan P2KP.

P2KP merupakan salah satu pilar mempertahankan dan meningkatkan ketahanan pangan serta membudayakan pola konsumsi yang Beragam, Bergizi, Seimbang dan Aman (B2SA), baik jumlah maupun mutunya guna meningkatkan kualitas konsumsi pangan masyarakat (BKP, 2010). Hal ini sejalan dengan salah satu target Kementerian Pertanian RI Tahun 2010-2014 yaitu peningkatan diversifikasi pangan, terutama untuk mengurangi konsumsi beras dan terigu. Selama tahun 2010-2014, konsumsi beras ditargetkan turun $1,5 \%$ per tahun 
yang diimbangi dengan peningkatan kualitas konsumsi pangan yang berasal dari umbi-umbian, pangan hewani, buahbuahan dan sayuran.

Tabel 1. Skor Pola Pangan Harapan Nasional

\begin{tabular}{ccc}
\hline Tahun & Skor PPH & Target \\
\hline $\mathbf{2 0 0 2}$ & 72,6 & 72,6 \\
$\mathbf{2 0 0 5}$ & 79,1 & 77,7 \\
$\mathbf{2 0 0 8}$ & 81,9 & 82,9 \\
$\mathbf{2 0 0 9}$ & 75,7 & 85 \\
$\mathbf{2 0 1 0}$ & 77,5 & 86,4 \\
$\mathbf{2 0 1 1}$ & 77,3 & 88,1 \\
$\mathbf{2 0 1 2}$ & 75,4 & 89,8 \\
\hline
\end{tabular}

Sumber: BKP, 2013

Tabel 1 di atas menunjukkan angka $\mathrm{PPH}$ yang masih fluktuatif dan belum sesuai target yang ditetapkan. Konsumsi padi-padian masih menduduki persentase paling besar sekitar 61,8\%, sedangkan konsumsi pangan hewani, sayur dan buah masih rendah (BKP, 2013:1). Sehubungan dengan hal tersebut, sebagai sebuah program nasional, Gerakan P2KP memerlukan dukungan dan fasilitasi pejabat sebagai pemangku kepentingan mulai dari tingkat Pusat, Provinsi, Kabupaten/Kota sampai tingkat Desa.

Salah satu provinsi yang memiliki komitmen dalam mendukung Gerakan P2KP adalah Jawa Tengah (Jateng). Pemerintah Provinsi Jawa Tengah berkepentingan terhadap suksesnya Gerakan P2KP karena salah satu tujuannya yaitu mengurangi
Kualitas konsumsi pangan masyarakat Indonesia dapat dicermati melalui Pola Pangan Harapan (PPH) dan dapat dilihat pada Tabel di bawah ini. ketergantungan terhadap bahan pangan pokok beras yang semakin meningkat seiring dengan laju pertumbuhan penduduk. Berdasarkan data BPS Jateng (2012:3), penduduk Jawa Tengah pada tahun 2010 telah mencapai 32,382 juta jiwa, meningkat menjadi 32,643 juta jiwa pada tahun 2011 dengan pertumbuhan rata-rata sebesar $0,76 \%$ per tahun. Sementara itu, terkait dengan jumlah pemenuhan kebutuhan pangan, produksi padi Jawa Tengah mengalami fluktuasi. Data BPS (2012) menunjukkan produksi padi Provinsi Jawa Tengah tahun 2010 mencapai 10,110 juta ton Gabah Kering Giling (GKG), tahun 2011 turun menjadi 9,391 juta ton dan tahun 2012 naik menjadi 10,232 juta ton, sedangkan pertumbuhan produktivitas padi periode 2000-2010 rata-rata sebesar 1,30\% per tahun.

Sebagai wujud dukungan terhadap Gerakan P2KP, maka Pemerintah Provinsi Jawa Tengah menindaklanjuti Peraturan Pemerintah Nomor 22 Tahun 2009 dengan mengeluarkan Peraturan Gubernur (Pergub) Nomor 41 Tahun 2009 tentang Pelaksanaan Gerakan Percepatan Penganekaragaman Konsumsi Pangan Berbasis Sumber Daya Lokal. Melalui Gerakan P2KP ini 
diharapkan pola konsumsi pangan masyarakat Jawa Tengah dapat dikelola dengan baik. Berdasarkan skor PPH periode 2010-2012, kualitas konsumsi pangan masyarakat terus menunjukkan peningkatan, yaitu 83,66 untuk tahun 2009; 86,03 pada tahun 2010; 88,66 untuk tahun 2011 dan 89,87 tahun 2012 (BKP Jateng, 2013: 2). Angka tersebut mengindikasikan bahwa kesadaran masyarakat akan konsumsi makanan yang B2SA semakin meningkat dan perlu terus didukung termasuk level pemerintah dibawahnya.

Kabupaten Klaten merupakan salah satu daerah yang memiliki kepedulian terhadap Gerakan P2KP. Klaten merupakan salah satu kabupaten di Jawa Tengah dengan jumlah penduduk yang cukup besar yaitu 1,378 juta jiwa pada tahun 2011 dan meningkat menjadi 1,461 juta jiwa pada tahun 2012 (BPS Klaten, 2013: 80). Berdasarkan data BPS, laju pertumbuhan penduduk Klaten rata-rata sekitar 0,90\% per tahun (BPS Klaten, 2013: 79). Peningkatan jumlah penduduk yang selalu positif setiap tahun di Kabupaten Klaten tersebut, tentunya menuntut adanya penyediaan pangan yang selalu meningkat.

Sementara itu, jumlah produksi padi di Kabupaten Klaten bersifat fluktuatif, yaitu pada tahun 2010 mencapai 302.893 ton dan menurun menjadi 206.815 ton pada tahun 2011, kemudian meningkat menjadi 387.089 ton pada tahun 2012 (BPS Klaten 2013: 217). Keadaan ini semakin mendorong pemerintah Kabupaten Klaten untuk terus berkomitmen dalam Gerakan P2KP. Komitmen ini diimplementasikan melalui Peraturan Bupati Klaten Nomor 11 tahun 2010 tentang Percepatan Penganekaragaman Konsumsi Pangan Berbasis Sumber Daya Lokal. Dalam pelaksanaannya, keberhasilan Gerakan P2KP bergantung pada sinergi antara aparat pemerintah daerah dari berbagai instansi terkait, penyuluh pendamping dan penerima manfaat.

Untuk menyukseskan Gerakan P2KP ini, diperlukan individu atau organisasi yang dapat menjadi fasilitator antara pemerintah dan petani. Salah satu pihak terkait yang tepat untuk menjalankan peran fasilitasi berbagai kebijakan pemerintah, agar dapat direalisasikan oleh petani adalah penyuluh pendamping. Mengingat perannya yang demikian penting, maka penyuluh pendamping perlu memiliki kompetensi yang memadai agar berbagai program kebijakan dapat berjalan efektif termasuk di Kabupaten Klaten.

Selanjutnya terkait dengan penyuluh pendamping P2KP di Kabupaten Klaten, terdapat faktor keterbatasan sumber daya penyuluh yang kurang memadai. Secara kuantitas, penyuluh di wilayah Kabupaten Klaten 
masih kurang, sehingga akan berpengaruh terhadap kualitas peran utamanya sebagai penyuluh pendamping P2KP. Berdasarkan data rekapitulasi penyuluh Tenaga Harian Lepas-Tenaga Bantu Penyuluh Pertanian (THL-TBPP) dan Sistem Informasi Manajemen Penyuluhan tahun 2013, jumlah penyuluh di Kabupaten Klaten berjumlah 189 orang, sedangkan jumlah wilayah desa binaan sebanyak 401 Desa.

Permasalahan lain yang terkait dengan pelaksanaan Gerakan P2KP di Kabupaten Klaten adalah masalah kompetensi penyuluh pendamping. Sebagaimana dikatakan oleh koordinator penyuluh pendamping P2KP bahwa sebagian dari penyuluh kurang dibekali tentang metode dasar penyuluhan dalam arti pelatihan yang dilaksanakan masih kurang. Tetapi karena keterbatasan tenaga penyuluh, maka sebagian penyuluh tersebut harus segera diterjunkan ke lapangan guna mendampingi sebuah program. Padahal pelatihan ini sangat penting dalam peningkatan kompetensi penyuluh pendamping dan mempunyai peran besar dalam implementasi program karena penyuluh dihadapkan pada berbagai permasalahan di lapangan.

Kondisi dan latar belakang
masyarakat yang beranekaragam
membuat tidak semua penyuluh
pendamping dapat melakukan
pendampingan P2KP dengan baik.

Pengaruh Peran Dan Kompetensi Penyuluh Pendamping Terhadap Keberhasilan GerakanPercepatan penganekaragaman Konsumsi Pangan (P2kp) Tahun 2014 Dalam Mendukung Ketahanan Pangan Di Kabupaten Klaten-Fajar Sriningsih | 176 penyuluh pendamping untuk dapat menyesuaikan perkembangan teknologi ditemukan informasi baru dalam proses pembelajaran. Penyuluh pendamping diharapkan mempunyai kemampuan untuk menyampaikan materi penyuluhan dengan metode yang partisipatif, menarik dan mudah dipahami sesuai dengan kondisi masyarakat setempat. Untuk dapat melakukan itu semua, maka diperlukan individu-individu yang mempunyai kompetensi, sehingga Gerakan P2KP dapat diterima dan dilaksanakan dengan baik oleh penerima manfaat.

\section{PERANAN PENYULUH}

Di Indonesia istilah penyuluhan terus mengalami perkembangan. Menurut Undang-Undang Nomor 16 Tahun 2006 tentang SP3K bab 1 pasal 1 memberikan pengertian terkait penyuluhan adalah proses pembelajaran bagi pelaku utama serta pelaku usaha agar mereka mau dan mampu menolong dan mengorganisasikan dirinya dalam mengakses informasi pasar, teknologi, permodalan dan sumberdaya lainnya. Untuk mencapai tujuan tersebut, maka terdapat beberapa peran yang sebaiknya dijalankan oleh penyuluh termasuk penyuluh pendamping Gerakan P2KP. Penyuluh pendamping P2KP memiliki dan informasi yang ada, sehingga selalu 
peranan sebagai sumber daya utama dalam mencapai keberhasilan Gerakan P2KP, termasuk didalamnya memperbaiki kualitas konsumsi pangan masyarakat. Mardikanto (2009), menyatakan penyuluh pendamping merupakan agen pembawa perubahan pada bidang pertanian. UU Nomor 16 Tahun 2006 tentang SP3K menyebutkan bahwa secara umum, terdapat tujuh peran utama dari penyuluh pendamping P2KP, antara lain sebagai: edukator, inovator, fasilitator, konsultan, supervisor, advisor, pemantau dan evaluator.

\section{KOMPETENSI PENYULUH}

\section{PENDAMPING}

Kompetensi individu diperlukan dalam menjalankan suatu peran dan tugasnya yang berhubungan dengan masyarakat umum termasuk masyarakat tani. Salah satu kegiatan yang berhubungan dengan masyarakat tani adalah penyuluhan pertanian. Untuk dapat berhasil dengan baik, maka penyuluhan pertanian diharapkan dilakukan oleh penyuluh yang berkompeten.

Kompetensi penyuluh menurut BPSDM Pertanian (2001 : 4) secara umum dapat dilihat dari pengetahuan, keterampilan dan sikap penyuluh dalam menjalankan kegiatan penyuluhan. Sejalan dengn BPSDM, Sutrisno (2011) menyatakan kompetensi merupakan suatu kemampuan yang dilandasi keterampilan dan pengetahuan yang didukung sikap kerja serta penerapannya dalam melaksanakan tugas dan pekerjaan di tempat kerja dengan mengacu persyaratan kerja yang telah ditetapkan. Berdasarkan pendapat Sutrisno (2011), dapat dianalogikan bahwa kompetensi penyuluh harus memenuhi standar pengetahuan, keterampilan dan sikap. Dengan demikian, kompetensi yang meliputi ketiga hal diatas yang dimiliki penyuluh pendamping dapat dinyatakan sebagai prasyarat bagi keberhasilan pelaksanaan Gerakan P2KP dalam mendukung ketahanan pangan di Kabupaten Klaten.

\section{GERAKAN PERCEPATAN PENGANEKARAGAMAN KONSUMSI PANGAN (P2KP) DAN KETAHANAN PANGAN}

Gerakan P2KP merupakan salah satu implementasi diversifikasi pangan yang tertuang dalam rencana strategis Kementerian Pertanian RI Tahun 20102015 dengan tujuan meningkatkan keanekaragaman pangan disesuaikan dengan potensi dan karakter masingmasing daerah. Untuk melihat keberhasilan dari implementasi Gerakan P2KP di lapangan dapat dilihat apakah pelaksanaan tersebut telah sesuai dengan rencana awal yang ditetapkan melalui indikator-indikator keberhasilannya.

Keberhasilan Gerakan P2KP yang 177 | Khazanah Intelektual Volume 2 Nomor 2 Tahun 2018 
dapat dilihat beberapa indikator sebagai berikut:

1) Meningkatkan jumlah partisipasi wanita dalam penyediaan pangan keluarga yang beragam, bergizi, seimbang dan aman.

2) Meningkatkan motivasi, partisipasi dan aktivitas masyarakat dalam Gerakan P2KP.

3) Meningkatkan pola konsumsi pola pangan masyarakat dilihat dari skor $\mathrm{PPH}$.

Keberhasilan Gerakan P2KP diharapkan dapat mendorong ketahanan pangan di suatu wilayah termasuk di Kabupaten Klaten. Ketahanan Pangan yang dimaksud dalam penelitian ini merujuk pada Undang-Undang Nomor 18 Tahun 2012 yang menyatakan, Ketahanan Pangan adalah Kondisi terpenuhinya pangan bagi negara sampai dengan perseorangan yang tercermin dari tersedianya pangan yang cukup, baik jumlah maupun mutunya, aman, beragam, bergizi, merata dan terjangkau serta tidak bertentangan dengan agama, keyakinan, dan budaya masyarakat untuk dapat hidup sehat, aktif dan produktif secara berkelanjutan. Gerakan P2KP merupakan salah satu upaya dalam meningkatkan ketahanan pangan khususnya peningkatan kualitas pangan. Kualitas pangan dapat dilihat dari penyajian pola menu sehari-hari dalam masyarakat yang mengandung B2SA. Indikator B2SA tercermin dalam $\mathrm{PPH}$ suatu wilayah.

\section{METODE PENELITIAN}

Penelitian ini menggunakan metode penulisan campuran (mixedmethods), yaitu metode penulisan kuantitatif dan metode penulisan kualitatif. Penelitian ini juga merupakan penelitian deskriptif. Nawawi (2003), menjelaskan bahwa penulisan deskriptif memusatkan perhatian pada masalah-masalah di lapangan saat dilakukan penulisan, kemudian menggambarkan fakta dari masalah yang diteliti dan dianalisis serta diinterpretasi secara rasional.

Selanjutnya strategi yang penulis gunakan dalam pengumpulan maupun analisis data adalah strategi embedded konkuren, yaitu strategi dalam metode campuran dengan menerapkan pengumpulan data kualitatif dan kuantitatif pada satu tahap secara bersamaan. Dalam strategi ini, pencampuran dilakukan ketika penulis akan mengomparasikan satu sumber data dengan sumber data yang lain, biasanya terjadi saat pembahasan penulisan. Beberapa data dalam penulisan dapat saja tidak dikomparasikan, tetapi dideskripsikan secara berdampingan sebagai dua gambaran yang berbeda sebagai interpretasi dari penggabungan 
permasalahan. Strategi ini biasanya digunakan dalam penulisan yang menggunakan dua rumusan masalah yang berbeda antara penelitian kualitatif dan kuantitatif.

Metode kuantitatif dalam penelitianini menggunakan populasi yaitu penyuluh pendamping Gerakan P2KP di Kabupaten Klaten yang berjumlah 36 orang. Selanjutnya untuk metode kualitatif, penulis melakukan wawancara untuk menggali beberapa informasi penting terkait dengan peran, kompetensi dan kontribusi Gerakan P2KP terhadap ketahanan pangan Kabupaten Klaten kepada pihak-pihak terkait seperti Kepala Seksi Konsumsi dan Penganekaragaman Pangan, Staf Bagian Konsumsi dan Penganekaragaman Pangan, Koordinator Penyuluh Pendamping Gerakan P2KP, Kelompok Sasaran Gerakan P2KP dan Kepala Desa Penerima Manfaat P2KP. Tujuan dari wawancara ini adalah untuk melakukan konfirmasi jawaban yang diajukan kepada penyuluh pendamping dan menjelaskan kontribusi Gerakan P2KP terhadap ketahanan pangan
HASIL DAN PEMBAHASAN

Peran Penyuluh Pertanian

Gerakan P2KP mulai dilaksanakan di Kabupaten Klaten sejak tahun 2010. Semenjak adanya gerakan P2KP menandakan bertambahnya tugas dan tanggung jawab yang harus diemban oleh para penyuluh di lapangan. Penyuluh yang dimaksud disini adalah penyuluh pendamping yang wilayah binaannya menjadi sasaran dari Gerakan P2KP tersebut. Tugas ini menjadi bagian dari peran yang harus dijalankan penyuluh secara keseluruhan sebagai agen perubahan dalam pembangunan pertanian. Peran penyuluh pendamping dalam mengawal Gerakan P2KP di Kabupaten Klaten terdiri dari peran sebagai edukator, peran sebagai inovator, fasilitator, konsultan, advisor, supervisor, pemantauan dan evaluator.

\section{Peran Penyuluh sebagai Edukator}

Peran penyuluh sebagai edukator terhadap keberhasilan Gerakan P2KP di Kabupaten Klaten dapat dijelaskan pada Tabel 2.

Kabupaten Klaten.

Tabel 2. Peran Penyuluh Sebagai Edukator

\begin{tabular}{clcc}
\hline No & \multicolumn{1}{c}{ Indikator } & Skor & Kategori \\
\hline 1. & $\begin{array}{l}\text { Materi penyuluhan sesuai dengan } \\
\text { kebutuhan }\end{array}$ & 4,208 & Tinggi \\
2. & Manguasai Materi & 4,263 & Tinggi \\
3. Meningkatkan Pengetahuan Keterampilan & 4,222 & Tinggi \\
\multicolumn{2}{c}{ Rata-Rata } & 4,231 & Tinggi \\
\hline
\end{tabular}

Sumber : Olahan Data Primer, 2014

179 | Khazanah Intelektual Volume 2 Nomor 2 Tahun 2018 
Berdasarkan hasil perhitungan Tabel 2 diketahui bahwa besarnya nilai rata-rata peran penyuluh sebagai edukator adalah 4,231 yang termasuk dalam kategori tinggi, hal ini menunjukkan bahwa sebagai edukator penyuluh pendamping telah memberikan materi penyuluhan sesuai dengan kebutuhan, menguasai materi dan meningkatkan

pengetahuan

dan

keterampilan dengan baik.

\section{Peran Penyuluh sebagai Inovator}

Peran penyuluh sebagai inovator terhadap keberhasilan Gerakan P2KP di Kabupaten Klaten dapat dijelaskan pada Tabel 3.

Tabel 3. Peran Penyuluh Sebagai Inovator

\begin{tabular}{llcl}
\hline No & \multicolumn{1}{c}{ Indikator } & Skor & Kategori \\
& & & \\
\hline 1. & Bekerjasama dalam memecahkan masalah & 4,180 & Tinggi \\
2. & Memberi solusi/saran & 4,222 & Tinggi \\
3. & Mengambil keputusan mengenai masalah & 4,277 & Tinggi \\
& Rata-Rata & 4,226 & Tinggi \\
\hline
\end{tabular}

Sumber : Olahan Data Primer, 2014

Berdasarkan hasil perhitungan

mengambil keputusan mengenai masalah Tabel 3 diketahui bahwa besarnya nilai dengan baik.

rata-rata peran penyuluh sebagai inovator adalah 4,226 yang termasuk dalam kategori tinggi, hal ini menunjukkan bahwa sebagai inovator penyuluh pendamping telah mampu bekerjasama dalam memecahkan

\section{Peran Penyuluh sebagai Fasilitator}

Peran penyuluh sebagai fasilitator terhadap keberhasilan Gerakan P2KP di Kabupaten Klaten dapat dijelaskan pada Tabel 4.

masalah, memberi solusi/saran dan

Tabel 4. Peran Penyuluh Sebagai Fasilitator

\begin{tabular}{cccc}
\hline No & Indikator & Skor & Kategori \\
\hline 1. & Menerapkan metode penyuluhan & 4,000 & Tinggi \\
2. & Adanya praktek dan pelatihan & 4,277 & Tinggi \\
3. & Memberikan teknik budidaya terbaru & 4,152 & Tinggi \\
& Rata-Rata & 4,143 & Tinggi \\
\hline
\end{tabular}

Sumber : Olahan Data Primer, 2014

Berdasarkan hasil perhitungan fasilitator adalah 4,000 yang termasuk Tabel 4 diketahui bahwa besarnya nilai dalam kategori tinggi, hal ini rata-rata peran penyuluh sebagai menunjukkan bahwa sebagai fasilitator 
penyuluh pendamping telah mampu menerapkan metode penyuluhan, mengadakan praktek dan pelatihan serta memberikan teknik budidaya terbaru.

\section{Peran Penyuluh sebagai Konsultan}

Peran penyuluh sebagai konsultan terhadap keberhasilan Gerakan P2KP di Kabupaten Klaten dapat dijelaskan pada Tabel 5.

Tabel 5. Peran Penyuluh Sebagai Konsultan

\begin{tabular}{llcc}
\hline No & \multicolumn{1}{c}{ Indikator } & Skor & Kategori \\
\hline 1. & Mengadakan Konsultasi & 4,055 & Tinggi \\
2. & Memperkenalkan Informasi Teknologi Baru & 4,167 & Tinggi \\
3. Kerjasama dengan Lembaga Terkait & 4,055 & Tinggi \\
4. Saling Tukar Pikiran mengenai Kendala & 4,138 & Tinggi \\
& Rata-Rata & 4,103 & Tinggi \\
\hline
\end{tabular}

Sumber : Olahan Data Primer, 2014

Berdasarkan hasil perhitungan baru, bekerjasama dengan lembaga Tabel 5 diketahui bahwa besarnya nilai terkait dan tukar pikiran mengenai rata-rata peran penyuluh sebagai kendala yang dihadapi. konsultan adalah 4,103 yang termasuk dalam kategori tinggi, hal ini menunjukkan bahwa sebagai konsultan penyuluh pendamping telah mampu mengadakan konsultasi, memperkenalkan informasi teknologi

\section{Peran Penyuluh Sebagai Advisor}

Peran penyuluh sebagai advisor terhadap keberhasilan Gerakan P2KP di Kabupaten Klaten dapat dijelaskan pada Tabel 6.

Tabel 6. Peran Penyuluh Sebagai Advisor

\begin{tabular}{clcc}
\hline No & \multicolumn{1}{c}{ Indikator } & Skor & Kategori \\
& & & \\
\hline 1. & Bimbingan Penyuluhan & 4,194 & Tinggi \\
2. & Mempunyai Pendapat & 4,263 & Tinggi \\
3. & Memberikan Bimbingan Teknik Budidaya & 4,277 & Tinggi \\
4. & Memberikian Informasi dan Pengarahan & 4,277 & Tinggi \\
& Rata-Rata & 4,252 & Tinggi \\
\hline
\end{tabular}

Sumber : Olahan Data Primer, 2014

Berdasarkan hasil perhitungan kategori tinggi, hal ini menunjukkan Tabel 6 diketahui bahwa besarnya nilai bahwa sebagai advisor penyuluh rata-rata peran penyuluh sebagai advisor pendamping telah mampu melaksanakan adalah 4,252 yang termasuk dalam bimbingan penyuluhan, mempunyai 181 | Khazanah Intelektual Volume 2 Nomor 2 Tahun 2018 
pendapat, memberikan bimbingan teknik

budidaya dan memberikan informasi serta pengarahan.

Peran Penyuluh Sebagai Supervisor
Peran penyuluh sebagai supervisor terhadap keberhasilan Gerakan P2KP di Kabupaten Klaten dapat dijelaskan pada Tabel 7.

Tabel 7. Peran Penyuluh Sebagai Supervisor

\begin{tabular}{cccc}
\hline No & Indikator & Skor & Kategori \\
& & & \\
\hline 1. & Membimbing dan Memotivasi & 4,083 & Tinggi \\
2. & Disiplin Kerja dalam Melaksanakan Kegiatan & 4,111 & Tinggi \\
3. & Komunikasi yang baik & 4,138 & Tinggi \\
& Rata-Rata & 4,110 & Tinggi \\
\hline
\end{tabular}

Sumber : Olahan Data Primer, 2014

Berdasarkan hasil perhitungan

disiplin kerja dalam melaksanakan

Tabel 7 diketahui bahwa besarnya nilai kegiatan dan komunikasi yang baik.

rata-rata peran penyuluh sebagai

Peran Penyuluh Sebagai Pemantau supervisor adalah 4,110 yang termasuk dan Evaluator

dalam kategori tinggi, hal ini

Peran penyuluh sebagai pemantau menunjukkan bahwa sebagai fasilitator penyuluh pendamping telah mampu dan evaluator terhadap keberhasilan melakukan bimbingan dan motivasi,

Gerakan P2KP di Kabupaten Klaten dapat dijelaskan pada Tabel 8.

Tabel 8. Peran Penyuluh Sebagai Pemantau dan Evaluator

\begin{tabular}{cccc}
\hline No & Indikator & Skor & Kategori \\
& & & \\
\hline 1. & Memberikan Arahan Pengembangan & 4,000 & Tinggi \\
2. & Membentuk Program Kerja & 4,083 & Tinggi \\
& Rata-Rata & 4,041 & Tinggi \\
\hline
\end{tabular}

Sumber : Olahan Data Primer, 2014

Berdasarkan hasil perhitungan arahan pengembangan dan memberikan Tabel 8 diketahui bahwa besarnya nilai program kerja dengan baik. rata-rata peran penyuluh sebagai pemantau dan evaluator adalah 4,041 Kompetensi Penyuluh Pertanian yang termasuk dalam kategori tinggi, hal

Berdasarkan hasil perhitungan data ini menunjukkan bahwa sebagai melalui SPSS, kompetensi penyuluh pemantau dan evaluator penyuluh pendamping pada GerakanP2KP di pendamping telah mampu memberikan Kabupaten Klaten masuk dapat dilihat 
dari nilai rata-rata jawaban responden adalah 213,06 yang berada pada interval 184-226. Nilai ini menunjukkan bahwa kompetensi penyuluh pendamping pada GerakanP2KP di Kabupaten Klaten termasuk dalam kategori baik.

\section{Kompetensi Penyuluh Berdasarkan Pengetahuan}

Kompetensi penyuluh berdasarkan pengetahuan terhadap keberhasilan Gerakan P2KP di Kabupaten Klaten dapat dijelaskan pada Tabel 9.

Tabel 9. Kompetensi Penyuluh Berdasarkan Pengetahuan

\begin{tabular}{llcl}
\hline No & \multicolumn{1}{c}{ Indikator } & Skor & Kategori \\
\hline 1. & Pengetahuan tentang Peran dan Tugas & 4,111 & Tinggi \\
2. & Pengetahuan tentang Regulasi & 3,935 & Tinggi \\
3. & Pengetahuan Perkembangan Teknologi & 3,930 & Tinggi \\
4. Pengetahuan Akses Pasar dan & 4,018 & Tinggi \\
& Pembiyaan & & \\
\multicolumn{2}{c}{ Rata-Rata } \\
\hline
\end{tabular}

Sumber : Olahan Data Primer, 2014

Berdasarkan hasil perhitungan

Peraturan Pemerintah dan kebijakan Tabel 9 diketahui bahwa besarnya nilai terkait dengan program P2KP, rata-rata kompetensi penyuluh pengetahuan perkembangan teknologi berdasarkan pengetahuan adalah 3,998 pertanian, metode atau penemuan baru yang termasuk dalam kategori tinggi, hal ini menunjukkan bahwa penyuluh pendamping mempunyai kompetensi yang baik tentang pengetahuan yang berhubungan dengan peran tugas dan tanggung jawabnya sebagai penyuluh (pendidik, inovator, fasilitator, konsultan, di bidang pertanian dan pengetahuan berhubungan dengan akses pasar dan pembiayaan (kredit)

\section{Kompetensi Penyuluh Berdasarkan Keterampilan}

Kompetensi penyuluh berdasarkan advokasi, supervisi dan monitoring); keterampilan terhadap keberhasilan pengetahuan yang berhubungan dengan Gerakan P2KP di Kabupaten Klaten regulasi seperti: Undang-Undang, dapat dijelaskan pada Tabel 10.

Tabel 10. Kompetensi Penyuluh Berdasarkan Keterampilan

\begin{tabular}{clcc}
\hline No & \multicolumn{1}{c}{ Indikator } & Skor & Kategori \\
\hline 1. & Kemampuan berkomunikasi & 3,889 & Tinggi \\
2. & Kemampuan Mengajar & 3,986 & Tinggi \\
3. & Keterampilan Sebagai Konsultan & 3,764 & Tinggi \\
4. & Kemampuan Membangun Hubungan & 3,759 & Tinggi \\
5. & Kemampuan Menjalin Kerjasama & 4,093 & Tinggi \\
\hline
\end{tabular}




\begin{tabular}{|c|c|c|c|}
\hline 6. & Kemampuan Memilih Metode yang Tepat & 3,750 & Tinggi \\
\hline 7. & Keterampilan Mendesain Metode Survey & 3,958 & Tinggi \\
\hline 8. & Kemampuan Mendiagnosa Masalah & 3,861 & Tinggi \\
\hline 9. & $\begin{array}{l}\text { Kemampuan } \quad \text { Beradaptasi } \\
\text { Lingkungan }\end{array}$ & 3,779 & Tinggi \\
\hline 10. & Keterampilan Memecahkan Masalah & 3,908 & Tinggi \\
\hline & $\begin{array}{l}\text { Rata-Rata } \\
\end{array}$ & 3,875 & Tinggi \\
\hline
\end{tabular}

Sumber : Olahan Data Primer, 2014

Berdasarkan hasil perhitungan

Tabel 10 diketahui bahwa besarnya nilai rata-rata kompetensi penyuluh berdasarkan keterampilan adalah 3,875 yang termasuk dalam kategori tinggi, hal ini menunjukkan bahwa penyuluh pendamping mempunyai kompetensi yang baik dalam kemampuan berkomunikasi, mendengarkan, mengobservasi, mengidentifikasi dan membuat laporan. Keterampilan dapat dilihat sebagai kemampuan mengajar dan menyakinkan seseorang; keterampilan sebagai konsultan untuk menolong orang lain; kemampuan untuk membangun hubungan dengan orang lain; kemampuan menjalin kerjasama dalam tim untuk merencanakan dan mengimplementasikan perubahan; kemampuan memilih metode yang paling tepat sesuai alokasi waktu yang disediakan; ketrampilan mendesain metode survey, wawancara dan pengumpulan data; kemampuan mendiagnosa masalah dengan rekanannya, mengalokasikan sumber bantuan, mengerti nilai-nilai dan budaya yang dianut oleh klien dan mendeterminasi kesiapan untuk perubahan; kemampuan beradaptasi dengan lingkungan yang ada dan keterampilan menggunakan teknik pemecahan masalah yang baik untuk diri sendiri maupun masalah orang lain.

\section{Kompetensi Penyuluh Berdasarkan Sikap}

Kompetensi penyuluh berdasarkan sikap terhadap keberhasilan Gerakan P2KP di Kabupaten Klaten dapat dijelaskan pada Tabel 11.

Tabel 11. Kompetensi Penyuluh Berdasarkan Sikap

\begin{tabular}{llcc}
\hline No & \multicolumn{1}{c}{ Indikator } & Skor & Kategori \\
\hline 1. & Pendekatan dalam Penyelesaian Masalah & 4,069 & Tinggi \\
2. & Bergaul dan Beriteraksi & 4,121 & Tinggi \\
3. & Pendekatan dalam Masalah & 4,092 & Tinggi \\
4. & Membimbing dan Menciptakan Kerjasama & 3,908 & Tinggi \\
5. Sikap terhadap Tugas dan Tanggung Jawab & 3,917 & Tinggi \\
6. Sikap pada Perkembangan IImu & 3,991 & Tinggi \\
& Pengetahuan & & \\
\hline \multicolumn{4}{c}{ Rata-Rata } \\
\hline
\end{tabular}

Sumber : Olahan Data Primer, 2014

Pengaruh Peran Dan Kompetensi Penyuluh Pendamping Terhadap Keberhasilan GerakanPercepatan penganekaragaman Konsumsi Pangan (P2kp) Tahun 2014 Dalam Mendukung Ketahanan Pangan Di Kabupaten Klaten-Fajar Sriningsih | 184 
Berdasarkan hasil perhitungan Tabel 11 diketahui bahwa besarnya nilai rata-rata kompetensi penyuluh berdasarkan sikap adalah 4,016 yang termasuk dalam kategori tinggi, hal ini menunjukkan bahwa penyuluh pendamping mempunyai kompetensi yang baik dalam pendekatan dalam menyelesaikan setiap masalah; bergaul dan berinteraksi dengan kelompok tani, kelompok masyarakat dan stakeholder lainnya; pendekatan dalam menyelesaikan setiap masalah; membimbing kelompok tani, menciptakan sinergi/kerjasama; sikap terhadap tugas dan tanggungjawabnya dan sikap terhadap perkembangan ilmu pengetahuan dan teknologi.

\section{Gerakan P2KP dalam Mendukung Ketahanan Pangan}

Gerakan P2KP merupakan salah satu upaya pemerintah untuk melaksanakan diversifikasi pangan dalam rangka mendukung ketahanan pangan nasional. Keseriusan pemerintah dalam melaksanakan program ini dapat dilihat pada Undang-Undang No 18 Tahun 2012 tentang Ketahanan Pangan, Peraturan Pemerintah Nomor 9 Tahun 2009, Peraturan Presiden Nomor 22 Tahun 2009 dan ditindaklanjuti melalui Peraturan Menteri Pertanian Nomor 43/Permentan/OT.140/10/2009 tentang Gerakan Percepatan Penganekaragaman
Konsumsi Pangan Berbasis Sumber Daya Lokal. Adapun tujuan dari gerakan P2KP ini adalah meningkatkan keanekaragaman pangan disesuaikan dengan potensi dan karakter masingmasing daerah.

Gerakan P2KP sebagai salah satu implementasi dari diversifikasi konsumsi pangan merupakan salah satu pilar ketahanan pangan masyarakat.Ketahanan Pangan yang dimaksud dalam penelitian ini mengacu pada Undang-Undang Nomor 18 Tahun 2012 yang mengedepankan pola konsumsi pangan yang mengandung B2SA. Gerakan P2KP mendorong masyarakat lebih kreatif dalam memanfaatkan lahan yang ada dengan menanam tanaman yang dapat digunakan untuk memenuhi kebutuhan gizi keluarga tanpa harus selalu mengeluarkan pendapatan yang besar. Dengan gerakan P2KP, pola konsumsi pangan masyarakat yang B2SA dapat membangkitkan ketahanan pangan keluarga masing-masing, yang berujung pada peningkatan ketahanan pangan nasional.

\section{Ketahanan Pangan dan Ketahanan Nasional}

Gerakan P2KP mendorong masyarakat sadar akan pola konsumsi pangan yang mengandung B2SA. Hal ini 
dikarenakan tidak ada satu bahan makanan yang mengandung semua zat gizi yang dibutuhkan tubuh. Dengan pola konsumsi yang B2SA maka kebutuhan zat gizi masyarakat dapat terpenuhi dari berbagai jenis makanan yang dikonsumsi. Terutama kebutuhan zat gizi mikro termasuk kebutuhan akan vitamin dan mineral dapat terpenuhi.

Dalam konteks lokal, Kabupaten Klaten melalui Peraturan Bupati Nomor 11 Tahun 2010 tentang Kebijakan Percepatan Penganekaragaman Pangan Berbasis Sumber Daya Lokal menjelaskan beberapa tujuan yang ingin dicapai dari gerakan P2KP ini. Adapun tujuan gerakan P2KP di Kabupaten Klaten adalah memfasilitasi dan mendorong terwujudnya pola konsumsi pangan beragam, bergizi, berimbang dan aman yang diindikasikan oleh skor $\mathrm{PPH}$ pada tahun 2015 sebesar 95 dan meningkatkan pengetahuan, ketrampilan dan sikap dalam mengubah perilaku masyarakat untuk mengkonsumsi pangan yang beragam, bergizi seimbang dan aman berbasis sumber daya lokal.

Saat ini, komitmen Kabupaten Klaten untuk mendukung gerakan P2KP sudah mulai nampak. Selama tiga tahun berjalan, gerakan P2KP ini telah memberikan kontribusi positif bagi peningkatan ketahanan pangan Kabupaten Klaten khususnya melalui diversifikasi pangan guna mendukung ketahanan pangan. Hal ini dapat dilihat dari terus meningkatnya skor Pola Pangan Harapan (PPH) Kabupaten Klaten sejak tahun 2010-2013. Secara berturut-turut skor PPH Kabupaten Klaten sebagai berikut tahun 2010 sebesar 81,6; tahun 2011 sebesar 83,1; tahun 2012 sebesar 87,3 dan tahun 2014 sebesar 89,9 .

Pencapaian ini tentu sesuatu yang menggembirakan. Kondisi ini menunjukkan bahwa masyarakat Klaten sudah cukup mampu memahami dan melaksanakan diversifikasi pangan yang tidak hanya bertumpu pada satu jenis pangan saja, namun terdiferensiasi pada jenis pangan lainnya. Pencapaian PPH yang setiap tahun meningkat ini juga menggambarkan bahwa masyarakat Klaten sudah mengonsumsi pangan dengan menu yang beragam, yang berarti gizi yang diperoleh juga tercukupi karena bahan makanan yang dimakan mengandung gizi yang beragam dan tidak hanya terfokus pada satu jenis makanan pokok saja, semisal nasi sebagai sumber karbohidrat.

Sebagaimana tujuan dari P2KP, yaitu memanfaatkan sebanyak mungkin pekarangan untuk melaksanakan diversifikasi pangan, maka hasil yang diperoleh dari peningkatan $\mathrm{PPH}$ Kabupaten Klaten setiap tahun tersebut memberikan realita bahwa masyarakat Klaten sudah mengoptimalkan peka- 
rangan untuk dimanfaatkan sebagai sumber pangan keluarga. Perolehan gizi dari hasil pangan yang ditanam di pekarangan rumah ini juga sangat optimal karena pangan yang ditanam dipupuk secara organik dan karenanya aman untuk dikonsumsi.

Gerakan P2KP ini telah menjadi salah satu kebijakan yang manfaatnya dan dampaknya dapat dirasakan secara meluas. Teknologi dan metode sederhana dalam implementasi gerakan P2KP telah mencerminkan bahwa gerakan ini dapat diterima oleh masyarakat, sehingga masyarakat dapat dengan mudah mengaplikasikannya.

Masyarakat lain yang belum menjadi kelompok sasaran dapat juga belajar bersama dengan kelompok sasaran dengan baik. Namun demikian, setiap program yang dilaksanakan pastilah menemui kendala dalam pelaksanaan-nya. Secara keseluruhan disimpulkan, gerakan P2KP di Kabupaten Klaten telah bisa terlaksana dengan baik. Hal ini tidak terlepas dari peran dan kompetensi yang dimiliki oleh penyuluh pendamping P2KP di Kabupaten Klaten.

Gerakan P2KP telah menjadi salah satu kebijakan yang dapat mendorong ketahanan pangan di Kabupaten Klaten. Skor PPH masyarakat Klaten yang terus meningkat sejak dikeluarkan gerakan P2KP ini mencerminkan bahwa pola konsumsi pangan masyarakat Klaten telah menunjukkan adanya perubahan yang positif, yaitu pola konsumsi yang beragam sehingga masyarakat telah memahami pentingnya gizi yang seimbang dan bahan makanan yang aman untuk dikonsumsi. Kualitas pangan yang dikonsumsi akan mempengaruhi kualitas individu dalam masyarakat. Individu yang berkualitas merupakan individu-individu yang tangguh dan ulet atau bisa dikatakan memiliki ketahanan yang kuat. Ketahanan individu yang semakin mantap secara makro akan mendorong ketahanan daerah yang semakin kuat menuju ketahanan nasional yang semakin mantap.

\section{Kesimpulan}

Berdasarkan hasil penulisan tentang pengaruh peran dan kompetensi penyuluh pendamping terhadap Gerakan Percepatan Penganekaragaman Konsumsi Pangan terhadap keberhasilan (P2KP) dalam mendukung Ketahanan Pangan daerah di Kabupaten Klaten dapat ditarik kesimpulan bahwa peran yang dilakukan penyuluh pendamping Gerakan P2KP di Kabupaten Klaten mempunyai kategori baik. Peran penyuluh pendamping mempunyai pengaruh yang signifikan terhadap keberhasilan Gerakan P2KP di Kabupaten Klaten yaitu sebesar 0,262 atau sekitar $26,2 \%$. Peran penyuluh pendamping yang mempunyai kategori 
tertinggi, yaitu peran penyuluh pendamping sebagai advisor, sedangkan indikator yang paling rendah adalah perannya sebagai pemantauan dan evaluator.

Kompetensi penyuluh pendamping terhadap Keberhasilan Gerakan Percepatan Penganekaragaman Konsumsi Pangan berpengaruh signifikan terhadap peningkatan keberhasilan P2KP untuk mendukung Ketahanan Pangan daerah di Kabupaten Klaten yaitu sebesar 0,101 atau 10,1 \%. Indikator kompetensi yang mempunyai kategori tinggi adalah sikap, sedangkan indikator yang paling rendah adalah keterampilan.

Gerakan P2KP telah menjadi salah satu kebijakan yang dapat mendorong ketahanan pangan di Kabupaten Klaten. Skor PPH masyarakat Klaten yang terus meningkat sejak dikeluarkan gerakan P2KP pada Tahun 2010-2013, yaitu skor PPH yaitu pada tahun 2010 sebesar 81,6; tahun 2011 sebesar 83,1; tahun 2012 sebesar 89,9 dan tahun 2013 sebesar 91,5. Selain itu Gerakan P2KP ini juga memberikan kontribusi dari aspek ekonomi dengan meningkatnya pendapatan kelompok sasaran. Hal ini sudah seseuai dengan tujuan penyuluhan pertanian secara umum meskipun tingkat keberhasilan baru mencapai $60 \%$.

\section{Saran}

1. Proses rekruitmen untuk penyuluh pendamping seharusnya dilakukan lebih selektif dan termasuk proses pemilihan wilayah yang menjadi sasaran program.

2. Kegiatan pemantau dan evaluasi sebaiknya ditingkatkan dari mulai perencanaan sampai pelaksanaan kegiatan ini.

3. Penyelenggaraan pelatihan sebaiknya ditingkatkan dan melibatkan berbagai pihak terkait terkait dalam setiap program termasuk kelompok sasaran dengan menyesuaikan anggaran yang tersedia.

4. Koordinasi antar pihak terkait perlu ditingkatkan dan menumbuhkan jiwa kebersamaan sehingga tidak muncul adanya ego sektoral.

\section{DAFTAR PUSTAKA}

BKP. 2013. Direktori Pengembangan Konsumsi Pangan. Jakarta: BPK Pusat. BKP.2013. Pedoman Umum Program Percepatan Konsumsi Pangan Tahun 2013. Jakarta: BKP Pusat.

BKP.2013. Pedoman Umum Program Percepatan Konsumsi Pangan Jawa Tengah. Semarang: BPK Jawa Tengah.

Badan Pengembangan Sumber Daya Manusia Pertanian, Departemen Pertanian. 2001. Penyusunan Standar Kompetensi Kerja Jabatan Fungsional: Laporan Pengkajian. Jakarta Pusat Pengkajian Sumber Daya Manusia Pertanian.

Badan Pusat Statistik. 2012. Jawa Tengah Dalam Angka 2012. Semarang: BPS Jawa Tengah.

Badan Pusat Statistik. 2012. Statistik Daerah Jawa Tengah 2012. Semarang: BPS Jawa Tengah. 
Badan Pusat Statistik. 2012. Statistik Indonesia. Semarang: BPS Pusat.

Badan Pusat Statistik. 2013. Produksi Tanaman Pangan. Semarang: BPS Pusat.

Biro Pusat Statistik. 2011. Statistik Tanaman Pangan Kabupaten Klaten 2011. Klaten: BPS Klaten.

Biro Pusat Statistik. 2012. Statistik Daerah Kabupaten Klaten Tahun 2012. Klaten: BPS Klaten.

Biro Pusat Statistik. 2013. Klaten Dalam Angka 2013. Klaten: BPS Klaten.

Mardikanto, Totok. 2009. Sistem Penyuluhan Pertanian. Surakarta: UNS Press.

Nawawi, Hadari. 2003. Manajemen Sumber Daya Manusia. Jakarta: PT. Bumi Aksara.
Rivai, V dan E.J. Sagala. 2010. Manajemen SDM Untuk Perusahaan: Teori dan Praktek. Jakarta: PT. Raja Grafindo Persada.

Sutrisno, Edy. 2011. Manajemen Sumber Daya Manusia. Jakarta : Prenada Media Group.

Umar.2004. Riset SDM Dalam Organisasi. Jakarta: PT. Gramedia Pustaka Utama.

Undang-Undang Nomor 16 Tahun 2006 Tentang Sistem Penyuluhan Pertanian, Perikanan dan Ketahanan.

Undang-Undang Nomor 18 Tahun 2012 Tentang Pangan. 